\title{
Perkembangan Akademi Teknik Radiodiagnostik dan Radioterapi (ATRO) Muhammadiyah Makassar, 1993-2018
}

\author{
Nursyamsi Selfi, Mustari Bosra, Bustan \\ Prodi Pendidikan Sejarah Fakultas Ilmu Sosial Universitas Negeri Makassar \\ nursyamsiselfy@gmail.com
}

\begin{abstract}
Abstrak
Penelitian ini bertujuan untuk menguraikan tentang sejarah dan perkembangan Akademi Teknik Radiodiagnostik dan Radioterapi (ATRO) Muhammadiyah Makassar, dengan mengungkapkan latar belakang berdirinya, perkembangan tenaga pendidik, tenaga administrasi, mahasiswa, kurikulum, sarana dan prasarana. Serta kontribusi ATRO Muhammadiyah kepada dunia pendidikan dan kepada masyarakat. Menggunakan metode historis dengan beberapa tahapan, kritik, historiografi. Hasil penelitian menunjukkan bahwa proses berdirinya ATRO Muhammadiyah Makassar dilatarbelakangi masih kurangnya tenaga rontgen khusunya di Kawasan Indonesia Timur. Awal berdirinnya tahun 1993, kampus ini bernama Akademi Penata Rontgen (APRO) , kemudian pada tahun selanjutnya yakni pada tahun 1995 berubah menjadi Akademi Teknik Radiodiagnostik dan Radioterapi (ATRO) Muhammadiyah Makassar. ATRO Muhammadiyah Makassar mengalami perkembangan. Hal ini dapat dilihat dari perkembangan sarana dan prasarana, tenaga pendidik, tenaga administrasi dan mahasiswa. Kontribusi yang diberikan ATRO Muhammadiyah Makassar yaitu memberikan kesempatan kepada masyarakat untuk menempuh Pendidikan Tinggi Kejuruan dibidang Radiologi. Selain itu lulusan ATRO Muhammadiyah Makassar bekerja di Instansi milik pemerintah maupun Swasta.
\end{abstract}

\section{Kata kunci : Kampus, Radiologi, dan Muhammadiyah}

\begin{abstract}
Abstrack
This study aims to describe the history and development of Akademi Teknik Radiodiagnostik dan Radioterapi (ATRO) Muhammadiyah Makassar, by revealing the background of its estabilihment, the development of educators, administrative staff, students, curuiculum, facilities, and infrastructure. And the contribution of ATRO Muhammadiyah to the world of education and to the community. Using the historical method with several stages, namely heuristics, criticism, interpretation and historiography. The results showed that the process of the establishment of ATRO Muhammadiyah Makassar was motivated by the lack of X-ray workers especially in Eastern Indonesia. Beginning in 1993, the campus was called Akademi Penata Rontgen (APRO), then in the following year in 1995 it was transformed into Akademi Teknik Radiodiagnostik dan Radioterapi (ATRO) Muhammadiyah Makassar. ATRO Muhammadiyah Makassar is experiencing growth. This can be seen from the development of facilities and infrastructure, teaching staff, administrative staff and students. The contribution provided by ATRO Muhammadiyah Makassar is to provide opportunities for the community to pursue a Vocational Higher Education in the field of Radiology. Besides that, ATRO Muhammadiyah Makassar graduates work in government and private institutions.
\end{abstract}

Keywords : Campus, Radiology, and Muhammadiyah 


\section{A. Pendahuluan}

Berdasarkan pembukaan UUD 1945, tugas umum pemerintah adalah mencerdaskan kehidupan bangsa. Sistem pendidikan nasional harus bertumpu pada nilai-nilai filosofis pancasila sehingga menjamin terwujudnya manusia seutuhnya yang beriman dan bertakwa kepada Tuhan Yang maha Esa menjunjung tinggi hak asasi manusia, cinta tanah air, menghargai ilmu pengetahuan teknologi dan seni, demokratis, dan memiliki tanggung jawab sosial dan kemasyarakatan. (Saleh, 2004) Pendidikan bagi bangsa yang sedang membangun seperti Indonesia saat ini merupakan kebutuhan mutlak yang harus di kembangkan tahap demi tahap. (Ihsan, 1997)

Melihat sejumlah masalah dewasa ini, seperti masalah sosial, kemiskinan serta keterbelakangan pendidikan. Maka dirasa perlu adanya pengembangan dan pemberdayaan dikalangan masyarakat terutama dalam bidang pendidikan.

Dewasa ini, potensi lembaga pendidikan Muhammadiyah cukup signifikan dan tersebar hampir di seluruh wilayah Indonesia. Dengan potensi pendidikan yang dimilikinya Muhammadiyah telah memberikan kontribusi yang sangat signifikan terhadap perkembangan pendidikan nasional dalam upaya mencerdaskan kehidupan bangsa. (Djamas, 2009) Adapun tujuan pendidikan Muhammadiyah menekankan pada moral yang berakar atau bersumber pada ajaran Agama Islam, lebih berdimensi religius. (Mohammad, Membeda Tujuan Pendidikan Muhammadiyah, 2016)

Oleh karena itu pada penelitian kali ini memfokuskan pada salah satu pendidikan tinggi berbentuk akademi yaitu Akademi Teknik Radiodiagnostik dan Radioterapi (ATRO) Muhammadiyah Makassar. ATRO Muhammadiyah Makassar merupakan Amal Usaha di kawasan Indonesia Timur yang berkedudukan di kota Makassar jenjang pendidikan kesehatan. ATRO Muhammadiyah adalah perguruan tinggi yang bergerak di bidang Radiologi. Menurut Patel, Radiologi adalah ilmu kedokteran untuk melihat bagian tubuh manusia yang menggunkan pancaran atau radiasi gelombang, baik gelombang elektromagnetik maupun gelombang mekanik. Radiologi terbagi 2 yaitu : Radiodiagnostik (untuk mendiagnosa penyakit menggunakan sinar-x) dan Radioterapi (untuk menterapi atau pengobatan penyakit menggunakan radiasi sinar-x).

ATRO Muhammadiyah Makassar Berdiri tahun 1993 oleh Pimpinan Wilayah Muhammadiyah Sulawesi selatan dengan nama semula Akademi Penata Rontgen (APRO). Berdirinya ATRO Muhammadiyah Makassar dilatar belakangi kurangnya tenaga rontgen dan belum adanya kampus radiologi khususnya di wilayah Indonesia Timur. Diawal berdirinya kendala yang dihadapi adalah kurang tenaga dosen, dalam hal ini dosen tetap. Oleh karena itu ATRO Muhammadiyah berusaha mencetak lulusan yang berkualitas kemudian melanjutkan ke jenjang pendidikan yang lebih tinggi dan bisa menjadi tenaga pendidik di ATRO Muhammadiyah Makassar.

Kajian relevan dalam suatu karya ilmiah perlu untuk ditelusuri guna mencari tahu apakah ide pokok suatu kajian sudah diangkat oleh penulis lain atau belum. Adapun kajian relevan berupa buku berjudul "Sejarah dan Pemikiran Pendidikan Islam" karya Suwendi tahun 2004, yang di dalamnya membahas pendiri organisasi Muhammadiyah beserta kelahiran Muhammadiyah itu sendiri. Selain itu buku berjudul "Sejarah Pendidikan Islam di Indonesia" karya Hasbullah tahun 2001, mengulas tentang usaha-usaha yang dilakukan Muhammadiyah sebagai organisasi islam yang mempunyai tujuan utama menyebarkan agama islam,salah satunya melalui pendidikan. 
Kemudian buku berjudul "Manajemen Perguruan Tinggi Beberapa Catatan” karya Syahrizal Abbas tahun 2008, didalam buku ini mendeskripsikan upaya pengembangan akademik, berupa penataan struktur kefakultasan, jurusan dan program studi, serta upaya peningkatan kualitas tenaga pengajar. Selain itu lebih khususnya buku berjudul "Manajemen Pendidikan Teknologi Kejuruan dan Vokasi” karya Basuki Wibawa tahun 2017. Pembahasan dalam buku ini sangat erat kaitannya dengan penelitian penulis. Karena penelitian penulis mengenai perguruan tinggi vokasi, dan pembahasan dalam buku ini menyeaikan beberapa topik manajemen pendidikan teknologi kejuruan dan vokasi.

Adapun kajian relevan berupa skripsi yang juga membahas tentang perguruan tinggi adalah Irwanto tahun 2011 jurusan pendidikan sejarah UNM, dengan judul Skripsi "Yayasan Pendidkan Turatea Indonesia (YAPTI) dan kiprahmya dalam pendidikan tinggi di Kabupaten Jeneponto (1985-2010)". Karya tersebut memaparkan mengenai awal didirikannya Yayasan Pendidkan Turatea Indonesia (YAPTI) yang didasarkan kenyataan yang dialami oleh lulusan SMA Jeneponto yang berhasrat kuliah di Ujung Pandang pada dekade 1980-an. Pada saat itu banyak lulusan SMA asal Jeneponto yang tidak tertampung di Perguruan tinggi di Makassar. Dari kenyataan tersebutlah, maka Rivai Pakihi sebagai pendiri berinisiatif untuk membangun perguruan tinggi di Kabupaten Jeneponto. Kajian relevan dalam bentuk jurnal dalam penelitian ini ditulis oleh (Purba A. I. \& Ponirin, 2013)

\section{B. Metode Penelitian}

Metode penelitian yang digunakan ialah kulitatif. Penulisan topik berkenaan dengan alasan peneliti mengangkat topik ini. Pengumpulan sumber berkenaan dengan pengumpulan data informasi. Verivikasi data sejarah berkenaan dengan pengumpulan data dan informasi. Verifikasi kritik sejarah berkenaan dengan uji keabsahan suatu sumber. Iterpretasi berkenaan dengan pencarian dan berkaitan makna antar fakta, sedangkan berkenaan dengan laporan hasil penelitian. (Kuntowijoyo, 2005) adapun tahap-tahap yang dilaukan dalam penulisan karya ini terdapat empat metode sejarah yang digunakan, yaitu :

\section{Heuristik}

Tahap ini merupakan tahap pengumpulan sumber-sumber yang relevan dengan topik yang penulis teliti. Tanpa sumber sejarah, kisah masa lalu tidak dapat di rekontruksi oleh sejarawan. (Madjid, Pengantar Ilmu Sejarah Makassar, 2008) Data diperlukan untuk menjawab masalah penelitian atau menguji hipotesis yang sudah di rumuskan. (Faisal \& Waseo, 1982) Penulis dalam mengumpulkan data yaitu menggunakan cara studi pustaka dengan mengumpulkan sumber buku-buku, data dan melakukan wawancara dengan pihak terkait. Adapun sumber buku didapatkan dari Perpustakaan Jurusan Pendidikan Sejarah Fakultas Ilmu Sosial, Perpustakaan Umum Universitas Negeri Makassar, Perpustakaan Universitas Muhammadiyah Makassar, Perpustakaan Wilayah Kota Makassar dan toko buku Gramedia. Selain itu pengumpulan data dan sumber bukubuku juga dilakukan dengan wawancara. Wawancara adalah upaya menggali informasi dari seseorang yang terlibat secara lanngsung. Dalam metode wawancara, penulis akan mewawancarai pihak-pihak yang dianggap dapat memberikan informasi primer tentang ATRO Muhammadiyah Makassar.

\section{Kritik}

Setelah sumber dikumpulkan maka tahap selanjutnya adalah melakukan kritik terhadap sumber yang didapatkan. Kritik terhadap sumber bertujuan untuk memperoleh fakta-fakta yang seobyektif mungkin, sehingga karya sejarah yang dihasilkan merupakan produk dari proses ilmiah yang dapat dipertanggungjawabkan , bukan hasil dari suatu fantasi maupun manipulasi guna untuk menetukan otensitas (keaslian sumber) dan kredibilitas (tingkat 
kebenaran informasi) sumber sejarah. (Madjid, Pengantar Ilmu Sejarah, 2008)

\section{Interpretasi}

Setelah dilakukan kritik diketahui validitas dan akurasi data penelitian untuk kemudian merekontruksi peristiwa yang terjadi, maka dilakukan penafsiran terhadap fakta sejarah yang diperoleh dalam bentuk penjelasan terhadap fakta tersebut seobjektif mungkin agar dapat diperoleh karya sejarah berkualitas. Penyimpulan data penelitian sejarah lebih melibatkan analisis yang masuk akal bukan analisis statistika. Oleh karena itu, peneliti harus bersikap seobyektif mungkin. (Sumanto, 1995)

\section{Hitoriografi}

Tahap ini merupakan tahap akhir dari metode sejarah, fakta-fakta yang telah dirumuskan dan diinterpretasikan selanjutnya dirangkai menjadi sebuah karya sejarah yang dipaparkan secara kronologis. Tentunya seorang penulis harus menungkan seluruh kemampuan daya bukan saja keterampilan teknis penggunaan kutipan dan catatan-catatan, yang paling utama yakni penggunaan pikiran-pikiran kritis dan analisanya karena sejarawan pada akhirnya harus menghasilkan sintesis dari seluruh hasik penelitiannya atau penemuannya itu dalam suatu penulisan utuh. (Sjamsuddin, 2012)

\section{Pembahasan}

\section{Muhammadiyah sebagai Gerakan Pendidikan dan Kesehatan}

Lahirnya beberapa organisasi Islam di Indonesia lebih banyak karena didorong oleh mulai tumbuhnya sikap patriotisme dan rasa nasionalisme serta sebagai respons terhadap kepincangan - kepincangan yang ada dikalangan masyarakat Indonesia pada akhir abad ke 19 yang mengalami kemunduran total sebagai akibat eksploitasi politik pemerintah kolonial Belanda. Langkah pertama diwujudkan dalam bentuk kesadaran berorganisasi. Walaupun banyak cara yang ditempuh oleh pemerintah kolonial waktu itu untuk membendung pergolakan rakyat Indonesia melalui media pendidikan namun tidak banyak membawa hasil, malahan menumbuhkan kesadaran tokoh-tokoh organisasi Islam untuk melawan penjajah Belanda, dengan cara menumbuhkan dan mengembangkan sikap dan rasa nsionalisme di kalangan rakyat melalui pendidikan. (Zuhairaini, 1997)

Harus diakui memang, umat Islam Indonesia sudah sejak lama memiliki lembaga pendidikan yang spesifik agama, yaitu pesantren. Namun harus diakui pula bahwa penyelenggaraan pendidikan agama model pesantren tersebut nampaknya sampai menjelang abad ke 20 boleh dikatakan tidak ada pengembangan sistem sama sekali. (Damami, 2000) Sebagai salah satu lembaga pendidikan islam yang masih berlangsung sampai sekarang, pesantren tentunya mengalami perkembangan.. Di abad 19, model pembelajaran pesantren hanya terfokus pada pelajaran-pelajaran islam dan belum memasukkan pelajaran umum, dengan demikian Belanda yang waktu itu masih menjajah Indonesia menganggap model pembelajaran tersebut membuat santri atau murid menjadi tidak berkembang.

Belanda menganggap pendidikan agama Islam dianggap tidak membantu pemerintah Belanda. Oleh sebab itu, Belanda mendirikan sekolah-sekolah dasar di tiap Kabupaten dimaksudkan untuk menandingi dan menyaingi madrasah, pesantren, dan pengajian di desa itu. Melihat tindakan pemerintah Belanda yang mulai menghambat pendidikan Islam diatas sehingga memungkinkan terjadinya kemunduran pendidikan Islam di Indonesia saat itu. Dengan begitu perlu adanya gerakan-gerakan yang dapat membendung tindakan Belanda, berdasar dari hal tersebut berdirilah organisasiorganisasi yang gerakannya mengarah ke pendidikan. Salah satu organisasi adalah Muhammadiyah. Melihat dari latar belakang berdirinya, Muhammadiyah hadir 
sebagai organisasi yang mendukung adanya gerakan perubahan kearah yang lebih baik. Organisasi ini didirikan di Yogyakarta pada tanggal 18 November 1912, oleh Kyai Haji Ahmad Dahlan. Organisasi ini mempunyai maksud "menyebarkan pengajaran Nabi Muhammad SAW kepada penduduk bumi putera" dan memajukan hal agama Islam kepada anggota-anggotanya, untuk mencapai ini organisasi itu bermaksud mendirikan lembaga-lembaga pendidikan, mengadakan rapat-rapat dan tabligh dimana dibicarakan masalah-masalah Islam. (Sunanto, 2012)

Muhammadiyah menuruti garis lurus yang telah digagas Ahsmad Dahlan sejak awal yaitu menuju ke pembaruan (Tajdid). (Baihiqi, 2013) Tentunya pembaruan ini dilakukan melihat kondisi umat Islam yang saat itu tertindas dari bagi aspek kehidupan sosial dan ekonomi, begitu juga dengan pendidikan. Peristiwa sejarah menunjukkan bahwa sejak awal Muhammadiyah begitu giat dan mengutamakan pendidikan, karena makna pendidikan dalam makna seluasluasnya merupakan kunci kemajuan kegemilangan suatu bangsa (masyarakat, kaum, negara). (Mohammad, Membedah Tujuan Pendidikan Muhammadiyah, 2016)

Pendidikan saat itu masih bersifat tradisional sehingga sangat sulit bagi santri untuk berkembang, Sebagai gerakan pembaruan, Muhammadiyah menyeimbangkan pelajaran agama dan pelajaran umum melalui modernisasi di bidang pendidikan. Ada dua jenis sekolah yang diasuh oleh Muhammadiyah. Pertama-tama sekolah-sekolah umum berbasis mata pelajaran umum dengan mata pelajaran agama sebagai ciri khas yang wajib diberikan di sekolah-sekolah Muhammadiyah. Kedua, sekolah-sekolah agama yang berbasis ilmu-ilmu keagamaan, sekolah-sekolah ini yang digolongkan kepada kelompok madrasah. (Daulay, 2007)
Setelah sukses dalam mengembangkan pendidikan di Indonesia, Muhammadiyah juga lahir sebagai organisasi yang bergerak di berbagai bidang dan aspek kehidupan manusia. Makna gerakan sosial dalam bidang kesehatan merupakan sebuah langkah Muhammadiyah dalam melakukan dakwah bil hal (dengan perbuatan) atau bukti nyata dengan melakukan pelayanan kesehatan. (Rohmansyah, 2017). Pelayanan kesehatan yang dilakukan oleh Muhammadiyah benar-benar di landaskan pada ajaran islam. Dalam hal ini tenaga kesehatan yang disediakan oleh Muhammadiyah haruslah yang benar-benar profesional. Adapun untuk menghasilkan tenaga kesehatan yang profesional, harus menempuh pendidikan terapan dalam satu cabang ilmu pengetahuan dan teknologi tertentu khususnya dibidang kesehatan. Untuk itu Muhammadiyah melalui amal usahanya berupaya untuk mendirikan sekolah dan perguruan tinggi yang menghasilkan lulusan yang ahli di bidang kesehatan. Sekaitan dengan penelitian penulis, Akademi Teknik Radiodiagnostik dan Radioterapi (ATRO) Muhammadiyah Makassar merupakan salah satu bentuk dari realisasi Organisasi Muhammadiyah sebagai gerakan yang bergerak dibidang pendidikan dan Kesehatan.

\section{Dari APRO Muhammadiyah ke ATRO Muhammadiyah}

Berdirinya Akademi Penata Rontgen (APRO) Muhammadiyah Makassar merupakan salah satu bentuk usaha dalam memperluas dan meningkatkan pelayanan kesehatan yang optimal kepada masyarakat., dengan begitu Departemen Kesehatan menempuh berbagai cara untuk membuat pelayanan ini lebih sempurna dan tenaga pelayanan yang cukup. Adapun langkah yang diambil dengan memberikan kesempatan kepada berbagai pihak untuk pengelolaan tenaga kesehatan melalui intuisi-intuisi resmi.

Melihat kesempatan tersebut, dalam hal ini Dr Subari selaku Majelis Pembina 
kesehatan berinisiatif untuk mendirikan perguruan tinggi di bidang Radiologi. Langkah pertama yang dilakukan yaitu di tahun 1993 bertemu dengan ketua perkumpulan Radiologi Indonesia Timur guna membicarakan rencana untuk mendirikan perguruan Tinggi di bidang radiologi. Dalam pertemuannya tersebut Majelis Pembina Kesehatan mendapat sambutan baik dari Dr. Adnan selaku ketua perkumpulan Radiologi Indonesia Timur. Setelah mendapat dukungan dan rekomendasi untuk mendirikan Perguruan Tinggi Radiologi dari Dokter Adnan selanjutnya membuat proposal pendirian Akademi Penata Rontgen (APRO) atas nama pimpinan Muhammadiyah Sulawesi Selatan.

Kemudian, Pimpinan Muhammadiyah melakukan Rapat Kerja Nasional tahun 1993 di Jakarta. Dalam Rapat Kerja Nasional tersebut Sekertaris Depatemen Kesehatan menjadi pemateri, dan melalui kesempatan itu menganjurkan Muhammadiyah untuk mendirikan 40 Akademi guna mengimbangi Akademi swasta yang ditangani Muslim dan Non Muslim. Akhirnya melalui anjuran tersebut, perwakilan Majelis Pembina Kesehatan dari daerah Sumatera Utara, Sumatera Selatan, Jawa Tengah, Jawa Timur, dan Sulawesi Selatan, mengutarakan kendala yang sama yaitu proposal yang telah dibuat belum mendapat persetujuan dan rekomendasi dari Kantor Wilayah setempat. Oleh karena itu, Sekertaris Departemen Kesehatan mengirim surat kepada masingmasing Kantor Wilayah untuk memberikan rekomendasi.

Setelah surat tersebut dibuat, satu bulan kemudian terbitlah SK (Surat Keterangan) pendirian dari Departemen Kesehatan untuk mendirikan Akademi Penata Rontgen (APRO) pada tahun 1993. Setelah berdrinya APRO, Majelis Pembina Kesehatan menunjuk Dr. Abdul Muin sebagai Direktur pertama.

Selain Direktur, untuk tenaga pendidik Dr Adnan selaku ketua perkumpulan Dokter Radiologi Indonesia Timur bersama Dr Bachtiar Razak selaku Sekertaris Perkempulan Dokter Radiologi Indonesia Timur, menyiapkan tenaga pendidik yang merupakan Dokter Radiologi dari Dokter Radiologi Indonesia Timur dan tenaga pendidik yang berasal dari Fakultas Kedokteran UNHAS bagian Radiologi.

Di awal berdirinya, untuk pengadaan alat-alat tersebut, maka Dr. Adnan meminta bantuan alat-alat Laboraturium kepada beberapa Rumah Sakit yaitu Rumah Sakit Labuang Baji, Rumah Sakit Wahidin dan Rumah Sakit Takalar. Bantuan ini berupa alat-alat yang sudah tidak digunakan pada rumah sakit tersebut unutk di berikan kepada APRO Muhammadiyah. Setelah alat-alat tersebut diberikan kepada APRO Muhammadiyah, pihak APRO Muhammadiyah memperbaiki alat-alal tersebut, secara fungsi alat-alat yang telah diberikan masih bisa digunakan hanya saja butuh perbaikan agar fungsinya dapat berjalan lebih baik.

Hal penting setelah pendirian sebuah perguruan tinggi adalah bagaimana cara untuk memperkenalkan APRO kepada masyrakat luas Dr. Subari melakukan promosi. Adapun jalan yang ditempuh untuk melakukan promosi tersebut yaitu dengan cara bertemu dengan seluruh Pimpinan Muhammadiyah Daerah dan menyampaikan mengenai pendirian sekolah Rontgen di Sulawesi Selatan.Melalui penyampaian tersebutlah maka masing-masing pemerintah daerah mengutus beberapa masyarakatnya untuk melanjutkan pendidikan di APRO Muhammadiyah. Adapun untuk 2 orang mahasiswa angkatan pertama berasal dari daerah Papua, yang mana mereka diutus oleh gubernur Papua untuk melanjutkan pendidikan di APRO Muhammadiyah Makassar. (Subari, 2019)

Dengan proses panjang hingga APRO Muhammadiyah dapat berdiri pada 8 September tahun 1993 melalui Surat Keputusan HK.00.06.1.1.3330, kemudian APRO Muhammadiyah berganti nama menjadi ATRO (Akademi Teknik 
Radiodiagnostik) pada tahun 1995. Kampus ATRO Muhammadiyah Makassar, berkedudukan di tengah kota Makassar beralamat: Jl. Ranggong Daeng Romo No. 21 dengan luas batas wilayah : $1.812 \mathrm{M}^{2}$.

Dengan demikian, berdirinya ATRO Muhammadiyah Makassar memberikan kesempatan bagi masyarakat khususnya setelah menempuh pendidikan menengah atas atau kejuruan untuk melanjutkan studinya ke jenjang yang lebih tinggi di bidang Radiologi.

\section{Perkembangan ATRO Muhammadiyah \\ Makassar \\ a. Sumber Daya Manusia \\ 1) Tenaga Pendidik}

Pada awal berdirinya ATRO

Muhammadiyah Makassar tahun 19931995 tenaga pengajar mata kuliah khusus dari kalangan dokter radiologi, umumnya dari kedokteran bagian radiologi Universitas Hasanuddin. Untuk meningkatkan SDM (sumber daya manusia), maka ATRO Muhammadiyah Makassar telah berusaha semaksimal mungkin memberikan kesempatan kepada tenaga pengajar melanjutkan pendidikan. Sampai tahun 2000 tercatat dua orang tenaga pengajar melanjutkan pendidikan yakni jenjang $S 2=1$ orang dan jejang D.IV $=1$ orang. Selain jumlah dosen tetap pada saat itu masih sedikit, tenaga dosen dengan lulusan D.III masih digunakan.

Untuk dosen hingga tahun 2018 memiliki pendidikan terakhir S3, S2, dan S1. Meskipun sudah tidak ada lulusan D.III yang menjadi tenaga pendidik, tetapi masih ada lulusan S1 sebanyak 8 orang yang menjadi tenaga pendidik.

Meskipun demikian pihak ATRO Muhammadiyah Makassar terus melakukan upaya untuk meningkatkan tenaga pendidik. Dengan begitu tenaga pendidik di ATRO Muhammadiyah mengalami peningkatan jumlah, ini bisa dilihat dari jumlah tenaga pendidik ditahun 2018 .

Hingga tahun 2018 perubahan signifikan yang dapat dilihat adalah tenaga pendidik di ATRO Muhammadiyah Makassar mengalami perkembangan dari segi jumlah dan kualitas. Selain itu jumlah tenaga pengajar atau dosen dengan lulusan D.III sudah tidak ada.

Dosen honorer yang menagajar minimal berlatarbelakang pendidikan S1 selebihnya dosen honorer didominasi lulusan magister atau S2. Dengan demikian tenaga pendidik pada ATRO Muhammadiyah Makassar baik itu statusnya sebagai dosen tetap maupun dosen honorer mengalami perkembangan baik dari segi jumlah maupun kualitasnya.

\section{b. Tenaga Administrasi}

Tenaga Administrasi ATRO

Muhammadiyah Makassar pada tahun 1997 sampai tahun 2000 berasal jadi segala jenjang pendidikan. Jumlah tenaga administarsi dengan pendidikan S.1 berjumlah 7 orang, pendidikan D IV satu orang, pendidikan D.III sebanyak 4 orang dan lulusan SMA sebanyak 3 orang. Sekaitan dengan hal tersebut, ATRO Muhammadiyah Makassar berusaha meningkatkan kemampuan tenaga administrasi untuk melanjutkan pendidikan dan pelatihan yang lebih tinggi.

Dalam perkembangan selanjutnya, tenaga Administrasi ATRO Muhammadiyah Makassar tahun 2013 sampai 2015 mengalami peningkatan baik dari segi jumlah maupun kualitas. Untuk jumlah sebanyak 27 orang dengan kualifiaksi pendidikan S.2 sebanyak 3 orang, S.1 sebanyak 13 orang, D.IV sebanyak 2 orang, D.III sebanyak 5 orang, dan lulusan SMA sebanyak 4 orang. Peningkatan kualitas tenaga administrasi yang mana hingga tahun 2000 belum terdapat tenaga administrasi dengan pendidikan S.2, oleh karena itu ATRO Muhammadiyah Makassar terus melakukan pengembangan.

Perkembangan dari segi kualitas terus ditingkatkan, ini terlihat ditahun 2015 hingga tahun 2018 jumlah tenaga Administrasi dengan pendidikan S.2 berjumlah 7 orang, pendidikan S.1 berjumlah 11 orang, D.III berjumlah 2 orang dan lulusan SMA sebanyak 4 orang.

\section{c. Mahasiswa}


Jumlah mahasiswa pada ATRO Muhammadiyah Makassar juga turut mempengaruhi dalam proses perkembangan kampus. Adapun ATRO Muhamadiyah Makassar merupakan suatu wadah yang bisa melahirkan tenaga Radiografi yang profesional sekaligus mampu melayani kebutuhan masyarakat.

Jumlah mahasiswa mengalami fluktuasi atau perubahan yakni pada 5 tahun ajaran yaitu tahun 1993/1994, 1994/1995, 1995/1996, 1996/1997, dan tahun ajaran 1997/1998. kemudian 4 tahun ajaran selanjutnya jumlah mahasiswa cukup stabil dalam artian tidak mengalami penrunan ataupun peningkatan yakni pada tahun 1998/1999, 1999/2000, 2000/2001, dan 2001/2002. Lalu 5 tahun ajaran berikutnya kembali mengalami fluktuasi atau perubahan. Kemudian pada tahun ajaran 2007/2008 sampai tahun ajaran 2016/2018 jumlah mahasiswa mengalami peningkatan. Adapun jumlah mahasiswa terbanyak terjadi pada tahun ajaran 2016/2017 yakni sebanyak 171, sedangkan jumlah mahasiswa paling sedikit yakni pada tahun ajaran 1993/1994 yakni sebanyak 37. Hal ini disebabkan karena di awal berdirinya tahun 1993 hingga tahun 1996 jumlah ruang kelas hanya satu. Selain itu pasang surutnya jumlah mahasiswa ATRO Muhammadiyah Makassar karena mahalnya biaya kuliah di ATRO Muhammadiyah Makassar. (Rusli, 2019)

\section{d. Kurikulum dan Sistem Pembelajaran}

Untuk menyesuaikan dengan perkembangan zaman dan pendidikan yang diselenggarakan pada ATRO Muhammadiyah Makassar maka dilakukan beberapa upaya. Upaya yang dilakukan oleh ATRO Muhammadiyah Makassar yaitu dengan melakukan pengembangan kurikulum. Untuk pengembangannya sendiri ATRO Muhammadiyah Makassar pada awalnya mengacu pada kurikulum yang telah di tetapkan dalam SK Mentri Pendidikan dan Kebudayaan tanggal 3 Januari 1996 tentang kurikulum yang berlaku secara nasional prodram Diploma III teknik Radiodiagnostik, serta SK Mentri
Kesehatan RI tanggal 17 januari 1997 tentang Kurikulum Program Diploma III Teknik Radiodiagnostik di lingkungan Departemen Kesehatan, yang mana kurikulum tersebut sebanyak 121 SKS.

Adapun dalam proses belajar mengajar di ATRO Muhammadiyah Makassar, kehadiran sangat menetukan bagi mahasiswa ATRO Muhammadiyah Makassar. Jika tidak memenuhi kehadiran mahaiswa tujuh puluh lima persen $(75 \%)$ maka mahasiswa tidak dapat mengikuti ujian akhir semester, dan jalan keluarnya yaitu ikut ujian semester yang akan datang. Ada metode diterapkan dalam pembelajaran yakni Ceramah, Diskusi, serta Praktikum.

Selain kehadiran mahasiswa, evaluasi juga dilaksanakan. Evaluasi di Intuisi ATRO Muhammadiyah Makassar terdapat Mid Semester yang diadakan oleh dosen dan evalusai semester dilaksanakan oleh akademik dengan pelaksanaan selama satu pekan.

Dalam perkembangan selanjutnya diadakan perubahan kulikulum. Penyelenggaraan pendidikan di ATRO Muhammadiyah Makassar dilaksanakan atas dasar kurikulum yang berlaku dan sudah ditetapkan oleh Kemenkes dengan pesetujuan Kopertis. Kurikulum yang digunakan merupakan kurikulum tahun 2014.

Selain interaksi dosesn dan mahasiswa yang dilakukan dalam proses belajar mengajar didalam kelas, ATRO Muhammadiyah Makassar sebagai pendidikan yang bergerak di pendidikan vokasi atau profesi maka dilakukan praktikum. Oleh karena itu pihak ATRO Muhammadiyah Makassar melakukan kerja sama yaitu MoU (Momerandum Of Understanding) dengan beberapa Instansi baik milik pemerintah maupun swasta.

\section{e. Sarana dan Prasarana}

Sarana dan prasarana di ATRO Muhammadiyah Makassar tahun 2000 yakni Ruang Direktur, Ruang Administrasi Umum, Ruang Administrasi Pendidikan dan Kemahasiswaan, Ruang Unit 
Perpustakaan, Ruang Laboraturium, Ruang Komputer, Ruang Kelas dan Musholla. Untuk ruang kelas jumlahnya saat itu hanya 3 kelas, yang mana kelas dilengkapi dengan papan tulis, kursi kuliah, kursi dosen, jam dinding dan kipas angin. Oleh karenanya pihak ATRO Muhammadiyah Makassar terus meningkatkan sarana dan prasarana.

Peningkatan sarana dan prasarana hingga tahun 2015 yaitu jumlah ruang kelas bertambah menjadi 5. Selain itu untuk kenyamanan dan efisiensi dalam ruang belajar maka setiap kelas dilengkapi dengan pendingin ruangan / AC, LCD, White Board, dan Wifi. peningkatan tidak hanya pada ruang kelas, tetapi juga dengan ruangan lain, yakni dengan diperadakannya Ruang Administrasi Umum, Ruang Pertemuan, Ruangan Senat Mahasiswa, dan beberapa ruangan lainnya. Untuk melihat sarana dan prasarana ATRO Muhammadiyah Makassar tahun 2015 dapat dilihat pada lampiran.

Dalam perkembangan selanjutnya, sarana dan prasarana ATRO Muhammadiyah Makassar mengalami perkembangan. Peningkatan jumlah mahasiswa turut menjadi faktor perkembangan sarana dan pra sarana pada ATRO Muhammadiyah Makassar. Yang mana pada tahun 2018 jumlah ruang kelas menjadi 6, dan untuk fasilitas di setiap ruang kelas masih sama seperti tahun 2015 . Selain ruang kelas, untuk menunjang praktikum yang dilakukan di kampus maka di tahun 2018 jumlah laboraturium mengalami peningkatan.

\section{Kontribusi ATRO Muhammadiyah Makassar}

\section{a. Terhadap Dunia Pendidikan}

ATRO Muhammadiyah Makassar merupakan pendidikan tinggi dalam penyiapan lulusan yang mampu bekerja dan siap berprofesi. Ini sejalan dengan tujuan didirikannya ATRO Muhammadiyah Makassar untuk menghasilkan tenaga Radiografi. Petingnya tenaga Rontgen karena alat-alat Radiologi penting untuk mendiagnosa dan mengobati suatu penyakit, oleh karenanya dibutuhkan sumber daya manusia yang mampu mengoperasikan alat-alat tersebut. Dengan begitu untuk mengaplikasikan alat-alat Radiologi tersebut maka dibutuhkan keahlian khusus, dan keahlian khusus tersebut bisa diperoleh melalui pendidikan.

Untuk itu dibutuhkan intuisi yang mampu mencetak tenaga Rontgen, sejalan dengan hal tersebut maka pemerintah berinisiatif mendidirkan pendidikan kejuruan atau vokasi dibidang Radiologi. Meskipun pemerintah sudah mendirikan pendidikan tinggi dibidang Radiologi, tetapi nyatanya masih belum mencukupi tenaga Rontgen khususnya di wilayah Indonesia Timur. Oleh karenanya Muhammadiyah berinisiatif untuk mendirikan sekolah Rontgen, melalui Amal Usahanya yakni ATRO Muhammadiyah Makassar. Selain mencetak tenaga Rontgen, ATRO Muhammadiyah Makassar juga berperan dalam mencetak tenaga pendidik atau Dosen, yang mana setelah belajar di ATRO Muhammadiyah Makassar melanjutkan pendidikan ke jenjang yang lebih tinggi.

Dengan begitu berdirinya ATRO Muhammadiyah Makassar turut membantu pemernitah dalam usaha mencerdaskan kehidupan bangsa. Yang mana ATRO Muhammadiyah Makassar memberikan kesempatan kepada masyarakat untuk melanjutkan pendidikan, khusunya pendidikan kejuruan atau vokasi dibidang radiologi pada tingkat Perguruan Tinggi.

\section{b. Kontribusi ATRO kepada masyarakat}

ATRO Muhammadiyah Makassar merupakan perguruan tinggi berbentuk Akademi. Akademi merupakan perguruan tinggi yang menyelenggarakan pendidikan vokasi dalam satu atau beberapa cabang Ilmu Pengetahuan dan/atau Teknologi tertentu.

Institusi pendidikan pada dasarnya tidak hanya memikirkan bagaimana mencetak mahasiswa menjadi berkualitas tetapi juga harus memikirkan bagaimana lulusan yang dihasilkan dapat di terima di pasar kerja. (Saputra, 2015) Oleh karena itu sebagai pendidikan vokasi dibidang teknologi, maka ATRO Muhammadiyah 
berperan penting dalam menyediakan sumber daya manusia (SDM) yakni sebagai tenaga rontgen.

Dalam rangka menghasilkan tenaga kerja radiologi profesional, ATRO Muhammadiyah Makassar telah menjajaki kerja sama dengan berbagai institusi yang berhubungan dengan kompetensi lulusannya dan biasanya dilakukan dalam bentuk magang kerja. Kerja sama ini ditujukan untuk kemampuan mahasiswa juga untuk memberi kesempatan kepada mitra kerjasama untuk menilai kemampuan mahasiswa, selain itu melalui kerja sama ini mahasiswa memperoleh pengalaman dan wawasan sebagai bekal yang dapat digunakan dalam dunia kerja.

Jadi ATRO Muhammadiyah Makassar menyelenggarakan pendidikan dengan sistem yang memadukan antara fungsi pendidikan yang menyiapkan sumber daya manusia seutuhnya dengan pelatihan atau praktikum yang berperan untuk menyiapkan lulusan yang siap bekerja atau berkarir pada bidang pendidikan Radiologi.

Setelah mahasiswa menempuh pendidikan tinggi, mereka selanjutnya akan menjadi alumni. Setelah para mahasiswa lulus dan menjadi mereka akan bersiap untuk masuk dunia kerja. (Muhson, 2012) Banyaknya peralatan rontgen di Rumah Sakit, maka sangat besar peluang alumni ATRO Muhammadiyah Makassar untuk bekerja di Rumah Sakit Pemerintah maupun swasta.

\section{Kesimpulan}

Berdasarkan uraian pembahasan yang telah dipaparkan maka kesimpulan yang dapat diangkat sebagai berikut, masih kurangnya tenaga rontgen khususnya di wilayah Indonesia Timur menjadi latar belakang Pimpinan Wilayah Muhammadiyah Sulawesi Selatan untuk mendirikan sekolah rontgen yakni ATRO Muhammadiyah Makassar. Berdirinya ATRO Muhammadiyah Makassar juga mendapat dukungan dari beberapa pihak yakni Depkes Sulawesi Selatan, Ketua Perhimpunan Dokter Spesialis Radiologi dan Fakultas Kedokteran Universitas Hasanuddin bagian Radiologi.

ATRO Muhammadiyah Makassar dalam mengalami perkembangan baik itu sarana prasarana yang menunjang proses belajar menagajar, jumlah tenaga pendidik, tenaga administrasi serta mahasiswanya.

Hadirnya ATRO Muhammadiyah Makassar dapat memberikan kontribusi dalam membantu pemerintah di bidang pendidikan kejuruan atau vokasi, serta turut berkontribusi dalam memberikan pelayanan kesehtaan khususnya dibidang Radiologi kepada masyarakat.

\section{DAFTAR PUSTAKA}

Akib, H. (2009). Dasar dasar teori organisasi. Makassar: Badan Penerbit UNM.

Baihiqi, M. (2013). Enisklopedia Tokoh Pendidikan. Bandung: Nuansa Cendekia.

Budiman, A. (2016). Hikayat Kretek. Jakarta: PT.Gramedia.

Damami, M. (2000). Akar Gerakan Muhammadiyah. Yogyakarta: Fajar Pustaka Baru.

Daulay, H. P. (2007). sejarah pertumbuhan dan pembaruan pendidikan islam. Jakarta: Kencana.

Djamas, N. (2009). Dinamika Pendidikan Islam di Indonesia Pasca Kemerdekaan. Jakarta: PT RajaGrafindo Persada.

Faisal, S., \& Waseo, M. G. (1982). Metodologi Penelitian Pendidikan. Surabaya: Usaha Nasional.Ihsan, F. (1997). Dasar Dasar Kependidikan. Jakarta: PT Rineka Cipta.

Kuntowijoyo. (2005). Pengantar Ilmu Sejarah. Yogyakarta: Bentang.

Maadjid, A. R. (2004). Pengantar Ilmu Sosial. Yogyakarta: Ombak.

Madjid, M. S. (2008). Pengantar Ilmu Sejarah. Makassar: Raihan.

Madjid, M. S. (2008). Pengantar Ilmu Sejarah. Makassar: Rayhan Intermedia. 
Madjid, M. S. (2008). Pengantar Ilmu

Sejarah Makassar. Makassar: 2008.

Mohammad, A. (2016). Membeda Tujuan

Pendidikan Muhammadiyah. Jurnal

Studi Islam, 43-56.

Mohammad, A. (2016). Membedah

Tujuan Pendidikan

Muhammadiyah. Jurnal Studi

Islam, 44.

Muhson, A. (2012). Analisis Relevansi

Lulusan Perguruan Tinggi. Jurnal

Economia, 48.

Purba, A. I., \& Ponirin. (2013).

Perkembangan Amal Usaha

Organisasi Muhammadiyah di

Bidang Pendidikan dan kesehatan.

Jurnal Ilmu Pemerintahan dan

Sosial Politik UMA, 101-111.

Purba, I. A., \& Ponirin. (2013).

Perkembangan Amal Usaha

Muhammadiyah di bidang

Pendidikan dan Kesehatan. Jurnal

Ilmu Pemerintahan dan Sosial

Politik, 110.

Rohmansyah. (2017). Kuliah

Kemuhamdiyaan. Yogyakarta:

LP3m.

Rusli, M. (2019, April 30).

Saleh, A. R. (2004). Madrasah dan

Pendidikan Anak Bangsa. Jakarta: RajaGrafindo Persada.

Saputra, U. (2015). Manajemen Pendidikan Perguruan Tinggi. Bandung: Refika Aditama.

Sjamsuddin, H. (2012). Metodologi Sejarah. Ombak: 2012.

Subari. (2019, Maret 6). Wawancara.

Sumanto. (1995). Metodologi Penelitian Sosial dan Pendidikan. Yogyakarta: Andi Offset.

Sunanto, M. (2012). Sejarah Peradaban Islam Indonesia. Jakarta: PT Grafindo.

Zuhairaini. (1997). Sejarah Pendidikan Islam. Jakarta: Bumi Aksara. 